\title{
World War I and the fall of the Ottomans: Consequences for South East Europe
}

\author{
Eugene Rogan
}

The big issues dividing the Ottoman Empire from the Balkan states had to do with demography and territory - before, during, and after the Great War. Thrace, Macedonia and the Aegean Islands were lands heatedly contested between the Ottomans and their Balkan neighbours. To some extent, those disputes were violently resolved through the two Balkan wars of 1912 and 1913. Balkan nationalist movements had impressed on both Turkey and its neighbours a false sense of incompatibility between Muslims and Christians that led implacably towards a homogeneously Christian Balkans and a homogeneously Muslim Anatolia. The means used were called 'population transfers' at that time; today we would refer to them as 'ethnic cleansing'. Whatever the rhetoric, the devastating consequences for the populations involved have left enduring scars that by far transcended the period of the Great War, and paved the way for a Greco-Turkish antagonism that proved to be one of the enduring features of the international relations of the Mediterranean world in the Twentieth Century.

In the early months of 1914, just before the outbreak of war, the European Powers tried to broker peace negotiations to resolve the outstanding differences between the Ottoman Empire and its Balkan neighbors. To some degree, the injection of foreign capital helped. France's loan of a $\$ 100$ million to assist in economic reconstruction in the Ottoman Empire went a long way to induce the Ottomans to accept their losses in Albania, Macedonia and Thrace, by promising real economic growth after two terrible wars. Yet even after the peace agreements had been signed and the terms of the loan concluded, there remained significant issues outstanding between Istanbul and Athens.

The peace agreements left Greece in possession of three key Aegean islands seized from Turkey in the Balkan Wars. Chios and Mytilene, dominating the entry to Smyrna (modern Izmir), were within sight of the Turkish mainland. Limnos, with its strategic harbor Mudros, was less than $80 \mathrm{~km}$ from the straits of the Dardanelles. The Porte never accepted the loss of these islands, and was unwilling to live with Greece dominating its coastal waters through possession of these islands. While Ottoman diplomats sought European support for their government's claims for the restoration of the Aegean islands, Ottoman war planners worked to shift the balance of naval power in the Mediterranean instead.

The Ottoman government commissioned two state-of-the-art dreadnoughts as their solution to the naval imbalance of the Eastern Mediterranean. The British shipbuilders Vickers and Armstrong took the commission in August 1911 for delivery three years later. The orders were placed as part of a British naval mission to help modernize the Ottoman fleet. The two ships Sultan Osman and the Reşadiye, named for the first and latest Ottoman sultans, were a tremendous drain on the Ottoman treasury. Appealing to Ottoman patriotism, the government funded the ships in large part through public subscription. Turkish schoolchildren were encouraged to contribute their pocket-money, and fund-raising stands were opened across Ottoman cities. Those who made a contribution of five piasters or more were allowed to hammer nails into massive wood blocks. While the ships became a focus of Ottoman pride, redressing the Empire's naval forces after the defeats in Libya of 1911 and the two Balkan wars, Greece and Russia were much less enthusiastic about these developments. The massive battleships would give the Turkish navy the advantage over the Russian Black Sea fleet but also dramatically shift the balance of power in the Aegean.

The Aegean islands dispute, and the impending delivery of British dreadnoughts to the Ottoman navy, raised the real prospect of war between Greece and Turkey in the first half of 1914. Officials in Greece were calling for pre-emptive strikes against the Ottoman navy before they took delivery of these two dreadnoughts. The Ottomans for their part prepared their citizens once again for war by dispatching mobilization posters to village headmen to hold until further notice. As it turned out those mobilization posters would not be used for war against Greece but would be posted when the Ottomans mobilized for the Great War in August that year. 
On August 2, 1914, the Ottoman Empire concluded a secret mutual defense pact with Germany which was, for all intents and purposes, a war alliance. The Turks presented the Germans with their war aims four days later, when the Germans desperately sought entry for two of their naval vessels into the neutral and sealed Straits of the Dardanelles. In a pre-dawn meeting with Ambassador Wangenheim on 6 August, Prime Minister Said Halim Pasha laid out his government's conditions for allowing the Goeben and Breslau to enter the Straits. Said Halim presented six demands of Germany that represent in a sense the earliest statement of Ottoman war aims in the Great War.

Two of Said Halim's conditions addressed recent Ottoman losses in the Balkans. First, the Ottomans were determined to secure agreements with Romania and Bulgaria before entering into any hostilities against the Triple Entente, to ensure that its Balkan neighbors would not threaten Turkish Thrace or Istanbul. The Grand Vizier also sought German assistance in concluding the "indispensable understandings with Rumania and Bulgaria" and in negotiating "a fair agreement with Bulgaria" for an equitable division of "possible spoils of war". In this way, Said Halim Pasha was laying out the possibility that if the war went particularly well for the Central Powers, the Ottomans might actually recover some of the territory they surrendered in the Balkan Wars in 1912-13.

Secondly, should Greece enter the war on the side of the Entente Powers, and be defeated, Germany would assure the return of the three Aegean islands of Chios, Mytilene (Lesbos) and Limnos to Turkish sovereignty.

So much for the geographical issues. Equally serious were the demographic divides between Muslims and Christians in the Balkans and Anatolia.

In their short time in power the Young Turks had overseen extensive population transfers. Territorial losses in the Balkan Wars drove waves of destitute Muslims to seek refuge in Ottoman domains. Without the resources to address this humanitarian crisis, the Turkish leadership created space for these Balkan refugees by deporting thousands of Ottoman Christians to Greece. A government committee then oversaw the reallocation of the houses, fields, and workshops of deported Ottoman Christians to help with the resettlement of Muslims coming from the Balkans. These "population exchanges" were regulated by agreements concluded between the Porte and the Balkan states, in this sense, ethnic cleansing with an international seal of approval. ${ }^{1}$

The deportation of ethnic Greeks from the Ottoman Empire served several purposes. Deportation not only freed up homes and workplaces for the resettlement of Balkan Muslims, but it allowed the Ottomans to expel thousands of citizens whose loyalty to the Ottoman state was in doubt. There was thus a political element behind the resettlement. Tensions over the Aegean Islands that threatened renewed war between Greece and the Ottoman Empire in the first six months of 1914 had left Ottoman Greeks vulnerable and exposed. The population exchanges initiated after the Balkan Wars had provided an internationally sanctioned solution to the Empire's "Greek problem".

What started as a controlled exchange of border populations between belligerents evolved into a systematic expulsion of ethnic Greeks from Ottoman lands more generally. Though there are no precise figures for these deportations, several hundred thousand Christians and Muslims were forcibly relocated before and during the First World War. The deeper the deportations were applied within Asian Minor, the more the government had to rely on violence and intimidation to achieve their aims. Ottoman Christian villagers in Anatolia, far from the troubled Balkans, resisted the state's efforts to uproot them from homes and villages in which they had lived for generations. Gendarmes rounded up villagers, beat the men, threatened to kidnap women, and even killed Ottoman Greeks who resisted deportation. Foreign consuls, appalled by the violence against Christian civilians, reported

\footnotetext{
${ }^{1}$ Taner Akçam, The Young Turks' Crime Against Humanity: The Armenian Genocide and Ethnic Cleansing in the Ottoman Empire (Princeton: Princeton University Press, 2012), pp. 63-96. Ryan Gingeras examines deportations and population exchanges along the southern coasts of the Sea of Marmara in Sorrowful Shores: Violence, Ethnicity, and the End of the Ottoman Empire (Oxford: Oxford University Press, 2009), pp. 12-54.
} 
dozens killed in some villages. Yet the expulsion of the Greeks from Anatolia could be carried out with a relatively low level of violence against individuals precisely because there was a Greece to which these people could be deported. Arguably this accounts for the different measures used towards Ottoman Greeks, who were uprooted and deported but not subjected to mass murder, and the Armenians, who faced genocide because they did not have a country to which they could be deported.

With the defeat of the Ottomans in October 1918, these issues were only exacerbated by the terms of the peace treaty. As Margaret MacMillan has so eloquently written in her earlier work, Peacemakers, Greek Prime Minister Venizelos had from the very start of the Paris Peace Conference pressed Greece's claims to Anatolia, but with mixed success. He gave dubious statistics to try and argue that the demography of the coastline of Turkey was overwhelmingly Greek. Venizelos was particularly adamant in making a claim to the port of Smyrna (Izmir). One of the Mediterranean boom towns of the nineteenth century, the pre-war population of Izmir was 250,000 "and more Greeks lived there than in Athens itself." Yet his bid for Smyrna and its hinterlands, reaching deep into Western Anatolia, created "a Greek province with a huge number of non-Greeks as well as a long line to defend against anyone who chose to attack from central Anatolia." ${ }^{2}$ Venizelos reinforced his claims to Smyrna and its hinterlands by reporting that Turks were massacring Greeks, and in this way secured an authorization from the Big Three to send a Greek cruiser off the coast of Smyrna. This was followed by the fateful decision of May 6, 1919 to dispatch Greek troops to protect the Greek community in Smyrna and its hinterlands. As we know, the landing of Greek soldiers on May 15, far from calming a tense situation, inflamed it and led to riots, violence, and gunfire that left 300-400 Turks and certainly no less than a hundred Greeks dead.

However destabilizing to the peace of Western Anatolia, the Greek claim to Izmir was formalized in the Treaty of Sèvres, imposed by the victorious Allied powers on the defeated Ottoman Empire (signed on the August 10,1920). Section IV of the Treaty, which treated the issues surrounding the future of Smyrna, created a kind of Greek condominium, using diplomatic double speak to make unpalatable matters seem positively reasonable. In a new formula, Smyrna was to remain under Turkish sovereignty, but Turkey was to transfer to the Greek government the exercise of her rights of sovereignty over Smyrna and its hinterlands. The Greek government was made responsible for the administration of Smyrna and would name its own officials to oversee the port and the territories behind it. The Greeks were allowed to garrison as many soldiers in Smyrna as they saw fit "for the maintenance of order and public security." They were to oversee the creation of a local parliament to be filled by people elected from the local population in an electoral process that was to be approved by the League of Nations. Relations between the Greek administration and a local parliament would be regulated within the terms of the Greek Constitution. In five years' time, the local parliament could petition the League of Nations for the incorporation of Smyrna into the Kingdom of Greece, at which point Turkish sovereignty would cease. In other words, one did not have to be a radical Turkish nationalist to see in the formula of the Treaty of Sèvres the transfer of a central part of Asia Minor from a Turkish to a Greek control.

The terms of the Treaty of Sèvres, duly signed by the powerless Ottoman government, set in motion the Kemalist rejection that would lead to war, the creation of the Turkish Republic, and the expulsion of the remaining Greek population from Anatolia.

It took until the September 10, 1922 before Ataturk entered Smyrna and declared it Izmir once and for all. The city was sacked and burned, and those who survived dispersed towards Greece as refugees. The war had created such antagonisms between Turks and Greeks in Anatolia that villagers across Thrace and Asia Minor abandoned their homes to join this exodus from Turkish territory. This population transfer was formalized by an agreement concluded between the governments of Greece and Turkey which arranged for a compulsory exchange of population involving 1.3 million Greeks from Anatolia and Thrace. The only exceptions to this expulsion were Greek residents of Istanbul

\footnotetext{
${ }^{2}$ Margaret MacMillan, Peacemakers: Six Months that Changed the World (London: John Murray, 2003), p. 441.
} 
(Constantinople), who had been living in the city prior to 1918. All Greeks from every other city and village were to be deported. In return, more than half a million Turks were expelled from Greece, with the exception of those Turks living in Western Thrace. Nearly two million people were displaced as a consequence of these actions.

Thus, the demographic differences were bridged by ethnic cleansing, and the territorial differences by war. Turkey achieved statehood in all of Anatolia, but Greece to this day still holds the three disputed Aegean islands.

As for the enduring legacy, one need only point to the Turco-Greek antagonism which had at so many points provoked crises in the Eastern Mediterranean, not least in Cyprus, to see that the harmful effects of the peace settlement marking the end of the First World War and the fall of the Ottomans. 